\title{
Social shaping of deep geothermal projects in Alsace: politics, stakeholder attitudes and local democracy

\author{
Philippe Chavot ${ }^{1 *} \mathbb{0}$, Christine Heimlich ${ }^{1}$, Anne Masseran², Yeny Serrano ${ }^{\text {, Jean Zoungrana }}{ }^{3}$ and Cyrille Bodin ${ }^{1}$
}

*Correspondence:
philippe.chavot@unistra.fr
'LISEC, University
of Strasbourg, 7
Rue de l'Université,
67100 Strasbourg, France
Full list of author information
is available at the end of the
article

${ }^{*}$ Correspondence: philippe.chavot@unistrafr LISEC, University of Strasbourg, 7 67100 Strasbourg, France is available at the end of the article

\begin{abstract}
This paper examines the social, cultural and political factors that favor or disrupt deep geothermal energy projects in Alsace. The research was conducted in the Risk Governance package of the H2020 DESTRESS program, aimed at comparing public perceptions of deep geothermal energy in different contexts. The French case studies focus on two different contexts: one in Northern Alsace, where geothermal energy is fairly well accepted, and another in the Eurometropolis of Strasbourg, where some projects have raised substantial controversy. Several conceptual tools are used to understand variations in the public perceptions of geothermal projects. First, the distinction between "locally anchored" projects and "unbound" or exogenous projects account for the way these projects take shape, based on dialog or facilitated by a favorable economic and national political context, ignoring local specificities. Second, the concepts of social identity and social worlds allow us to yield insights into the acceptability of a project on a more sociological and cultural level, instead of adopting a limited risk perception focus. By considering the social and cultural contexts, we can better explain the weight that opponents place in their discourses on induced risks, local politics, or environmental issues during a technoscientific controversy. This ultimately leads us to underline the limitations of the communication models for project governance that are chiefly aimed at reassuring the local population.
\end{abstract}

Keywords: Deep geothermal energy, Controversy, Energy transition, Public engagement, Alsace Upper Rhine Graben

\section{Introduction}

\section{Geothermal energy and energy transition}

The energy transition policy inaugurated in France in the early 2000s has led to major developments in deep geothermal energy through two important measures. First, the framework provided by the Grenelle laws $\left(2009 / 2010^{1}\right)$ prompted local and regional authorities to take concrete measures regarding green energy production. As such, the Renewable Heat Fund, created in 2009, targets renewable energy and energy recovery heat projects. As a result, the development of geothermal energy has resumed in

\footnotetext{
${ }^{1}$ Act no. 2009-967 of 3 August 2009 programming the implementation of the Grenelle for the Environment and Act no. 2010-788 of 12 July 2010 establishing a National Commitment regarding the Environment.
} 
the Paris basin (Boissavy et al. 2016). ${ }^{2}$ It has also encouraged provincial cities to integrate the development of geothermal energy into their regional climate plan, as in the Eurometropolis of Strasbourg (EMS). Additionally, Electricité de France (EDF)'s electricity purchase tariff was reviewed in 2010, setting the price of a $\mathrm{kWh}$ of geothermal energy at 20 cents. This last measure has ensured the economic viability of geothermal cogeneration/high-energy projects (producing electricity and heat) and led several companies to invest in the field and develop geothermal power plant projects (Chavot et al. 2019). However, although low-energy geothermal projects integrated into regional climate plans are typically well accepted by the population, this is not the case for geothermal cogeneration projects. Strong mobilizations against high-energy geothermal projects emerged in 2014 in the Haute-Savoie region and in Alsace. In the first case, local authorities argued that the operator's objectives contradicted regional climate plan priorities and that their region already produces enough electricity via hydroelectric power stations. In the second case, residents and several local officials in the EMS perceived geothermal cogeneration projects as too risky, and likely to do more harm than good. In addition, they felt that these projects were imposed and regretted that they did not find their place in a local master plan to enhance renewable energy.

\section{Research objective}

The purpose of this article is to examine how local governance clashes with the state framework in the field of energy transition. We examine the development of deep geothermal projects (GPs) in Alsace and the controversies they have sparked. This work builds on research carried out under the H2020 DESTRESS program. The "Risk Governance" section of this program consists in analyzing public perceptions of deep geothermal energy in different cultural, social, economic and political contexts. The French case studies focus on the factors leading to a favorable perception of the GPs in Northern Alsace and those leading to major controversies in the EMS.

We argue that the public perception of geothermal energy is affected by several factors. These factors may be related to the purpose of the project (producing electricity versus furnishing heat to local networks or industries), the coherence of the project with local policies, or the quality of the upstream dialog with the local population. We use several conceptual tools to help shed light on variations in public support to GPs. The distinction we propose between "locally anchored" and "unbound" projects accounts for the way that a project is socially shaped. "Locally anchored" projects are the outcome of a long, concerted dialog between operators and local actors, whereas "unbound" or exogenous ones are developed thanks to a favorable economic and national political context. They are externally managed and often ignore local specificities (Chavot et al. 2019). ${ }^{3}$ The social shaping of a project obviously affects its public perception and may elicit diverse reactions: somewhat consensual support in the case of locally anchored projects and criticism and resistance in the case of unbound projects. However, the form

\footnotetext{
${ }^{2}$ Since the early 2010, fifteen deep geothermal projects exploiting the Dogger aquifer (1600-1800 m) have been added to approximately thirty plants installed in the Paris basin in the 1980s.

3 In Chavot et al. (2019), we use the notions of "anchored" and "off-ground" projects as equivalents of "locally anchored" and "unbound" projects. The use of the term "unbound" has been inspired by a discussion with Olivier Ejderyan on what could be the best concepts to indicate such differences in the governance of geothermal projects.
} 
and strength of oppositional social movements or support to a project largely depends on the social situation and identity of the actors and stakeholders.

Two areas will be considered for this research. The first is the area of public expression, examined in particular through an analysis of the legal public inquiries (PIs) conducted in 2015/2016 in the EMS region. The second is the area of information, examined through the analysis of the media coverage and communication channels used by various actors. In addition, in-depth interviews with stakeholders (representatives of environmental and residents' associations and of local institutions, elected officials, journalists, scientists and industrialists) were conducted to help contextualize the results.

\section{Review of the literature and theoretical framework}

Perception of geothermal energy versus perception of concrete geothermal projects for heat and electricity production

Geothermal energy for heat and electricity production is an emerging source of renewable energy (RE) in some countries and regions, such as Australia, Switzerland, Netherlands, France and some Italian regions. In these places, public information about it may be scarce and resident populations often have no opinion on the issue. Thus, much of the sociological work on GE is prospective and evaluates, through questionnaire surveys and focus groups, how a population perceives the installation of a geothermal power plant. A sociological survey conducted in the Italian region of Viterbo (Pellizzone et al. 2017) revealed that the population was optimistic about the role that renewable energies, including geothermal energy, may play in the future. However, this optimism decreases when a plant is scheduled to be built in their immediate environment. The discussions in locally organized focus groups singled out potential obstacles to the projects: fears related to arsenic contamination of groundwater (a sensitive subject in the region) and lack of trust in local government.

Using an online focus group method with multiple discussion sequences, Carr-Cornish and Romanach (2014) analyzed the evolution of project perception when participants learn about the issue. A change of attitude is apparent in most people, especially regarding the risks of groundwater pollution or induced seismicity. These authors propose that this change occurs because informed participants balance the risks involved with the benefits and can adopt a more positive view. However, the issue of plant location remains an obstacle: despite a shared positive view of geothermal energy, most participants would prefer the drilling sites to be more than $100 \mathrm{~km}$ from their homes.

The discrepancy between an optimistic vision of RE and the expression of misgivings when facing local projects is not limited to geothermal energy. Many works on "social acceptability" have addressed this issue. Local opposition is often dismissed as informed by emotional, ignorance-fuelled reactions. The most radical conclusions (Gendron 2014) evoke a NIMBY (not in my backyard) syndrome to account for the alleged selfish attitude of opponents who are unable to grasp the technical dimensions and collective value of a project. However, this reductive interpretation of the resistance to the implementation of sociotechnical projects is based on a set of assumptions that, as Batellier (2015) and Devine-Wright (2011) show, rarely stand up to empirical scrutiny. It appears that opponents become quickly informed of the technical aspects of a controversial project. Therefore, it is necessary to move past interpretations that stigmatize the opposition to 
understand the dimensions of public response. In particular, one may ask whether the perception of risk, which may cause uncertainty and fear, is central in geothermal controversies and assess the prioritization of other concerns in the debates.

Meller et al. (2018) argue that environmental, economic and political concerns are common in public debates on deep geothermal energy. Discussions are often about the risks to the environment or housing, the cost-benefit balance for a community, and matters relating to the public's information or public consultation exercises. However, the population does not give equal importance to these elements in all case studies. Pellizzone et al. (2017) argue that economic, social and political contexts, the existence of seismic episodes in a region, and the degree of commitment of a population to environmental issues are elements that likely influence the way people think about deep geothermal projects. Thus, it is important to examine how these local factors influence the perception of geothermal projects.

\section{Understanding the social and cultural origins of social contestation}

The distinction between locally anchored and unbound projects accounts for the way that projects take shape in a region. This distinction allows for specifying whether a project is concerted with local policies or imposed and helps to understand the extent to which a project integrates local political, cultural, social, urban or environmental elements. However, this distinction has limited explanatory value regarding why and how a community or a group of actors supports or opposes a geothermal project. Indeed, imposed unbound projects are not necessarily contested by the local population and conversely, some inhabitants can oppose a locally anchored project. This article chooses to reflect on the local social dynamics leading to public support or social contestation of a GP. To do so, we draw inspiration from work conducted in the field of science and technology studies. This work allows for a better understanding of the meaning of local reactions to deep geothermal projects and accounts for the inclusion of geothermal energy in the agenda of stakeholders (politicians, associations, etc.).

Studying a different field, Wynne (1992) demonstrated that a controversy consists in a debate of ideas or a confrontation of arguments and is fuelled by personal relationships and confrontations between actors that could range from respect to arrogance. In his case study, he explained the attitude displayed by farmers in Cumbria, England towards experts tasked with the decontamination of the herds affected by the fallout from the Chernobyl cloud. The latter were confident in the efficiency of their technical knowledge and their laboratory models. They proposed the solutions they believed to be adapted to the situation and remained deaf to the farmer's suggestions/questions. Thus, the attitude and knowledge of experts appeared somehow to be a threat to what Wynne calls the social identity of the farmers, i.e., a set of beliefs, practices, cultural elements, constitutive of a way of living and experiencing a living space that is robust enough to withstand exogenous threats. As a result, the farmers' attitude towards the experts progressively shifted from trust to defiance. Our case studies similarly consider the relational aspect of controversies. Some GPs are conceived and initiated within a state policy framework, but their concrete implementation is carried out in a territory that is already grounded by the knowledge, know-how and social imagery of its inhabitants. 
Other approaches inspired by symbolic interactionism enable an understanding of the commitment and actions of the actors involved in a controversy. Garrety (1997) defines "social worlds" as relatively structured social units sharing a body of knowledge. These are characterized by a common commitment to priorities about what is important and what needs to be done. Each actor participates in different social worlds organized around religious or political convictions and the worlds of work, leisure, and community life. However, social worlds are not fixed entities but are constantly re-configured and re-organized. One of the main characteristics of social worlds is their supply of statuses, arguments, and resources intended to support the legitimacy of the actions and knowledge of the actors. For instance, one strategy that is often adopted in controversial situations is to redraw the boundaries of the scientific approach in an attempt to exclude all approaches deemed unscientific from the debate (Garrety 1997; Gieryn 1999). Our case study illustrates that point. During the controversy, several groups of residents and elected officials, involved in different social worlds, used statements from one scientist qualifying GPs as non-mature. In doing so, they attempted to disqualify the projects and enforce a precautionary principle. Conversely, industrialists used a number of technical and scientific arguments to promote their approach and incidentally exclude lay people from the discussion. Other references were brought forward to allow local residents to establish their legitimacy: the necessary energy transition, environmental protection, and compliance with democratic principles.

\section{Case studies and data sources}

\section{The case studies}

In Alsace, two geothermal power plants were in operation in 2015, and six applications for exploratory drilling had been submitted to the prefecture, five of which concerned the EMS region (Fig. 1). Three of these projects had been strongly contested in the public space during the legal public inquiries organized in the Spring of 2015. The Robertsau project was contested by residents' associations, and the Eckbolsheim and Mittelhausbergen projects were contested by the municipalities impacted by the projects. The mobilization was less significant in Illkirch-Graffenstaden and in Vendenheim. The projects planned in Northern Alsace did not provoke any hostile reaction at the time (Table 1).

The criticisms leveled against the projects vary from site to site. People express concern about the risks induced by drilling, and/or the operator's reliability, the absence of compensation for the host municipalities, and/or the projects' failure to consider environmental and urban planning constraints, or all of the above. However, all projects use similar technologies. With the exception of the Mittelhausbergen and Rittershoffen projects, all aim at producing heat and electricity, target an aquifer trapped in the granitic basement at $3000 \mathrm{~m}$ or deeper, and are inspired by EGS (enhanced geothermal system) stimulation research conducted in Soultz-sous-Forêts. Thus, to understand the change in perception of GE from one context to another, elements other than technical must be addressed: the local culture and society, the political and economic dimension of the projects, and the communication and public awareness-raising methods of the operators and local authorities. 


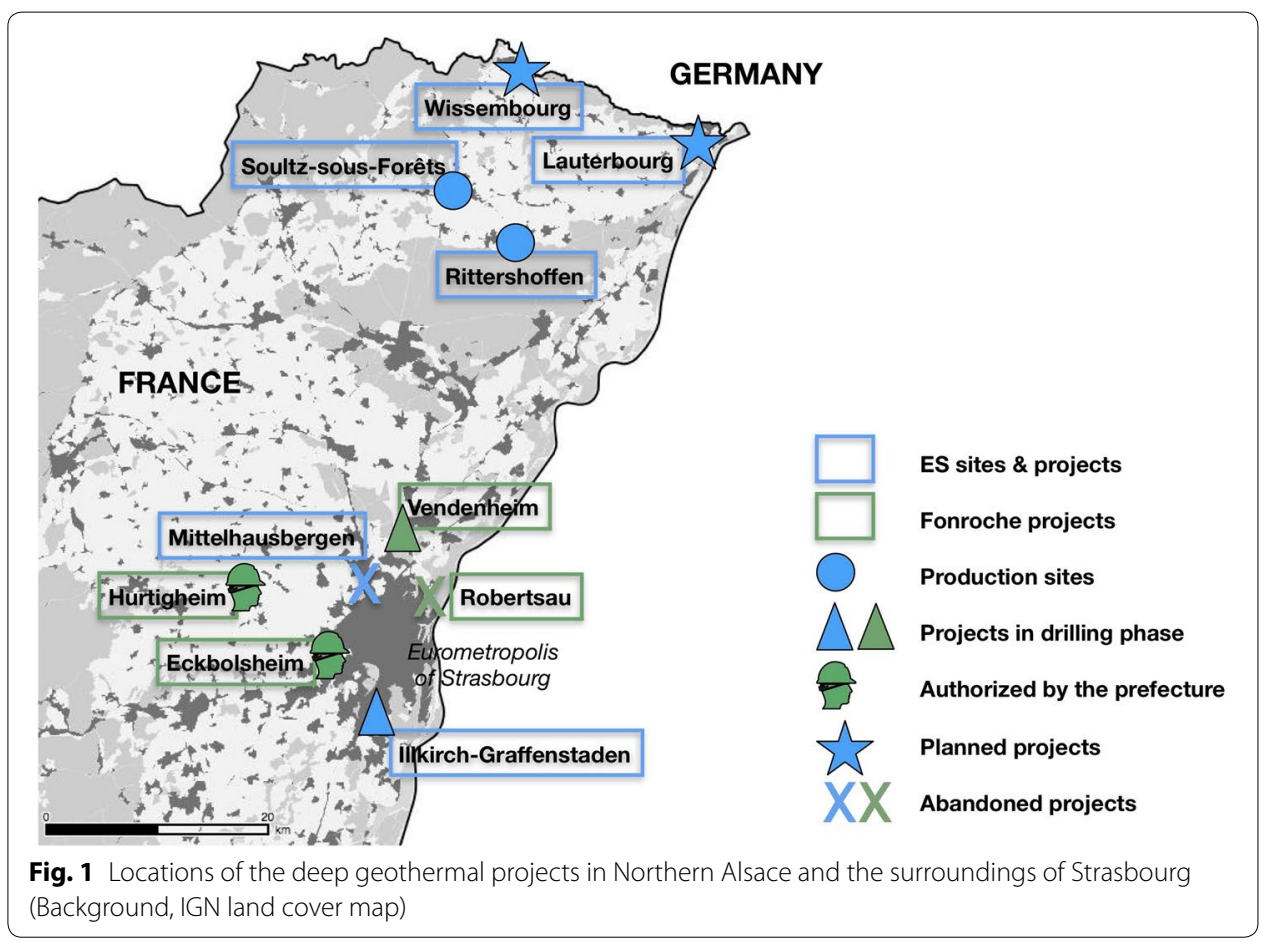

Table 1 Main geothermal projects in Alsace (heat between brackets means that the destination of produced heat has not been decided)

\begin{tabular}{|c|c|c|c|}
\hline $\begin{array}{l}\text { Sites and operators (ÉS: } \\
\text { Electricité de Strasbourg) }\end{array}$ & Depth: temp: flow & Production & Status \\
\hline \multicolumn{4}{|c|}{ Northern Alsace projects and plants } \\
\hline $\begin{array}{l}\text { Wissembourg and Lauter- } \\
\text { bourg area } \\
\text { ÉS }\end{array}$ & Not defined & Power (+ heat) & $\begin{array}{l}\text { Planned projects } \\
\text { No apparent contestation }\end{array}$ \\
\hline $\begin{array}{l}\text { Soultz-sous-Forêts } \\
\text { ÉS }\end{array}$ & $>3000 \mathrm{m:}: 165^{\circ} \mathrm{C}: 126 \mathrm{~m}^{3} / \mathrm{h}$ & Power (+ heat) & $\begin{array}{l}\text { Uncontested } \\
\text { In production }\end{array}$ \\
\hline $\begin{array}{l}\text { Rittershoffen } \\
\text { ÉS }\end{array}$ & $2500 \mathrm{~m}: 170^{\circ} \mathrm{C}: 160 \mathrm{~m}^{3} / \mathrm{h}$ & Heat & $\begin{array}{l}\text { Uncontested } \\
\text { In production }\end{array}$ \\
\hline \multicolumn{4}{|c|}{ Strasbourg Eurometropolis projects } \\
\hline $\begin{array}{l}\text { Illkirch-Graff. } \\
\text { ÉS }\end{array}$ & $\begin{array}{l}2900-3300 \mathrm{m:}: 150-160^{\circ} \mathrm{C}: \\
200 \mathrm{~m}^{3} / \mathrm{h}\end{array}$ & Heat + power & $\begin{array}{l}\text { Uncontested } \\
\text { Approved by prefecture } \\
\text { Drilling began in } \\
\text { August } 2018\end{array}$ \\
\hline $\begin{array}{l}\text { Mittelhausbergen } \\
\text { ÉS }\end{array}$ & $3800 \mathrm{~m}: 140-150^{\circ}: 180 \mathrm{~m}^{3} / \mathrm{h}$ & Heat & $\begin{array}{l}\text { Contested, then abandoned } \\
\text { (due to obsolete license) }\end{array}$ \\
\hline $\begin{array}{l}\text { La Robertsau (Strasbourg } \\
\text { quarter) } \\
\text { Fonroche }\end{array}$ & $\begin{array}{l}4300-4800 \mathrm{~m}:>150^{\circ} \mathrm{C}: 350 \\
\mathrm{~m}^{3} / \mathrm{h}\end{array}$ & Power (+ heat) & Contested, then abandoned \\
\hline $\begin{array}{l}\text { Eckbolsheim } \\
\text { Fonroche }\end{array}$ & $\begin{array}{l}4300-4800 \mathrm{~m}:>150^{\circ} \mathrm{C}: 350 \\
\mathrm{~m}^{3} / \mathrm{h}\end{array}$ & Power (+ heat) & $\begin{array}{l}\text { Contested } \\
\text { Approved by prefecture }\end{array}$ \\
\hline $\begin{array}{l}\text { Vendenheim } \\
\text { Fonroche }\end{array}$ & $\begin{array}{l}4000-4200 \mathrm{~m}:>150^{\circ} \mathrm{C}: 350 \\
\mathrm{~m}^{3} / \mathrm{h}\end{array}$ & Power (+ heat) & $\begin{array}{l}\text { Contested } \\
\text { Approved by prefecture } \\
\text { Drilling began in June } 2017\end{array}$ \\
\hline \multicolumn{4}{|l|}{ Other projects } \\
\hline $\begin{array}{l}\text { Hurtigheim } \\
\text { Fonroche }\end{array}$ & $\begin{array}{l}4300-4800 \mathrm{~m}:>150^{\circ} \mathrm{C}: 350 \\
\mathrm{~m}^{3} / \mathrm{h}\end{array}$ & Power (+ heat) & $\begin{array}{l}\text { Contested } \\
\text { Approved by prefecture }\end{array}$ \\
\hline
\end{tabular}


Table 2 Mandatory public consultations for low and high temperature geothermal energy

\begin{tabular}{|c|c|c|}
\hline & Low-temperature project & High-temperature project \\
\hline Depth and temperature & $\begin{array}{l}\text { Drilling depth over } 200 \mathrm{~m} \text {, } \\
<150^{\circ} \mathrm{C}\end{array}$ & $\begin{array}{l}\text { Drilling depth over } 200 \text { m, } \\
>150^{\circ} \mathrm{C}\end{array}$ \\
\hline Uses & $\begin{array}{l}\text { Heat for industries and urban heat } \\
\text { network }\end{array}$ & $\begin{array}{l}\text { Power and heat (greenhouses, } \\
\text { industries, heat network) }\end{array}$ \\
\hline $\begin{array}{l}\text { Application for an exclusive licence } \\
\text { to prospect (PER) }\end{array}$ & $\begin{array}{l}\text { Administered by the prefecture } \\
\text { Organization of a local public } \\
\text { inquiry }\end{array}$ & $\begin{array}{l}\text { Administered by the Ministry of } \\
\text { Mines } \\
\text { European competition } \\
\text { Public information and consultation } \\
\text { through the Minister web site }\end{array}$ \\
\hline Permit is issued & Prefectural decree, valid for 3 years & Ministerial decree, valid for 5 years \\
\hline Authorization of exploration work & $\begin{array}{l}\text { Administered by the prefecture } \\
\text { Organization of a public inquiry }\end{array}$ & \\
\hline
\end{tabular}

\section{Data sources}

We used several sources of data. First, we analyzed social mobilizations related to the 2015 and 2016 public inquiries. We also analyzed the communication strategies of the various stakeholders, media coverage of projects and public debates around geothermal energy.

\section{Source 1. Views and reports related to the 2015/2016 public inquiries}

The public inquiry (PI) mechanism is an old system whose scope was extended to environmental issues in 1983. PIs are organized at different times of the authorization procedures prior to drilling (Table 2).

Organized by the prefecture, the PI is hosted by the town hall and falls under the responsibility of an investigating commissioner (IC) mandated by the administrative court. ${ }^{4}$ Their duration is typically 1-2 months. During that time span, members of the public may visit the town hall to consult documents and give their opinion in a register. They may also send their opinion by mail or e-mail. The ICs play an important role in public information during the PI. They are requested to hold four reception sessions during which they facilitate access to the project's files by explaining and discussing them with citizens. When the participatory phase of the PI is over, the ICs gather, sort and summarize the comments, opinions, and proposals from citizens and send a report to the project promoter. In the last stage, they take into account answers provided by the promoter to write a subjective, argued opinion on the project, which can be positive, positive with reservations or negative. For this study, we focused on PIs organized in 2015 and 2016 as part of exploration works requests related to six projects located in or close to the EMS. We collected the 426 opinions submitted by French citizens ${ }^{5}$ as well as the documents presented by the operators and investigating commissioners. We also observed town hall meetings during which citizens confronted the investigating commissioners as well as several other public meetings and debates related to the PIs.

\footnotetext{
${ }^{4}$ An inquiry commission of several ICs is set up in the case of projects or license applications related to a wide area and involving several municipalities (as it is the case for requests for licenses to prospect related to low-energy geothermal projects).

${ }^{5}$ Over seven hundred German citizens contributed to the Robertsau PI. We left these contributions aside since our research mainly focuses on the debate involving local communities.
} 


\section{Source 2. Media reports and other communication supports}

For the purposes of this research, we focused on the September 2014-December 2015 period, to include media coverage of the public inquiries as well as public discourses on geothermal energy that had emerged prior the PIs. We collected articles about GPs from a selection of local press titles, i.e., the main regional daily newspaper Les dernières nouvelles d'Alsace (DNA) and the local online news website Rue89 Strasbourg. We also gathered texts from blogs, community newspapers and municipal and regional bulletins published in the Bas-Rhin region of Alsace. Communication documents proposed by operators, public meetings held by community groups and municipalities were also integrated into the corpus.

\section{Source 3. Interviews with stakeholders and other observations}

Interviews were conducted with 34 stakeholders from 2015 to 2017. We interviewed investigating commissioners, representatives of residents' and environmental groups, operators, scientists, elected officials of the municipalities affected by the projects and representatives of the EMS and prefecture. The interviews lasted from 1 to $2 \mathrm{~h}$ and included questions about the history of the projects and of their contestation, the roles, positioning of each organization and actor, and their perceptions of the roles of the media, citizens and national and local energy policies.

These three sources of documents and information complement each other: interviews help us to understand the communication plans of the stakeholders whose effects are partially visible in the media; analysis of the media and of other communication channels, together with interviews, sheds light on the informational context in which the PIs took place; lastly, analysis of citizens' opinions and PI documents yields insights into how the public receives and give meanings to the various sources of information circulating in the public space. Detailed analysis of the collected material (PI documents, press articles, interview transcripts) was performed using Atlas.ti software. This software allows to analyze themes, cited sources, and arguments in each document. It can perform quantitative analysis concerning, for example, the number of occurrences of the same argument in various public inquiries and in the media. Content analyses were also conducted to characterize how the media handled the information and to cross-reference the arguments proposed by citizens, by stakeholders and in media reports. Thus, it is possible to assess the use of the different types of resources by categories of actors, be they technical or linked to policies, cultural aspects or environmental ones, and to draw causal inferences related to stakeholders' inscriptions in different social worlds.

\section{Social worlds, public spaces and the role of the media}

\section{Social worlds and the circulation of information}

Participation in PIs is fuelled by debates taking place in various arenas. At the height of the controversy that took place in the EMS in 2014-2015, geothermal projects were under discussion in three spaces. First, community groups strongly opposed the Robertsau project, mainly through local residents' associations. These associations were alerted in the Spring of 2014 by German activists of the Citizens' initiative against deep geothermal energy in the southern upper Rhine area (Bürgerinitiative gegen Tiefengeothermie am südlichen Oberrhein), who denounced the risks associated with geothermal 
drilling. ${ }^{6}$ Articles were soon published in these groups' publications and blogs. Then, the three residents' groups of the northern and eastern districts of Strasbourg ${ }^{7}$ organized several information meetings. These meetings mobilized several hundred people, who were called upon to take part in the PI. Environmental protection groups such as Arbres (Association Ried Bruche pour le respect de l'environnement près de Strasbourg) and Alsace Nature also contributed to the debate.

The second arena is local politics. In the western EMS region, the projects were discussed in several municipal councils, which collected, discussed and diffused technical information on the GPs. These councils also held public meetings and used the forums of municipal newspapers and neighborhood councils to publicize their arguments. The media arena was a third space of debate for GPs in which stakeholders sought to be visible and gain credibility. We revisit this issue below.

These were not the only spaces in which discourse on GPs appeared. Operators and the EMS produced information sheets and web documents presenting the projects. In addition, the municipalities of Illkirch-Graffenstaden and Mittelhausbergen organized public meetings shortly before the PIs began. However, everything happened as if there were two opposed general categories of discourses in the public space. These discourses have their own rationale, i.e., they relay a coherent argument, mobilizing a set of resources and are related to specific social worlds (among others, those of industries and local institutions on one side, and those of residents' groups and local politics on the other).

The first was a discourse on geothermal energy, its links to energy transition and the value of building an energy mix, which generally left aside the issue of its inclusion in a given territory. This presentation of geothermal energy is found in the institutions' discourse and is often adopted by the regional press and in leaflets that operators produced to explain the projects to citizens. The second category of discourses highlighted how geothermal projects conflicted with the current dynamics within these territories. This is the discourse of community groups and municipal councils opposed to a project, and it is visible in public debates and texts published in municipal and community publications. These two categories of discourses appeared irreconcilable, as the meanings they gave to geothermal energy, science, risks and local territory were clearly different. The only convergence point could be found in the discourse of environmental protection groups, who aimed to constructively contribute to the public inquiries. They called for redesigning the projects to allow for better risk monitoring and more transparency visà-vis the population. One group called, for instance, for optimizing the use of subsoil heat by developing heat projects only. However, these discourses were too disconnected from the primary concerns of residents and elected officials to be considered during the PIs.

\footnotetext{
6 The arguments and agenda of this citizen's initiative can be consulted on https://www.bi-gegen-tiefengeothermi e-so.de/ (last accessed 13 Sept 2018).

7 L'Association pour la défense des intérêts de La Robertsau (ADIR), itself associated with the Association pour la Sauvegarde de l'Environnement de La Robertsau (ASSER) and the Association de Défense des Intérêts des Quartiers centreest de Strasbourg (ADIQ).
} 


\section{Is contrasting media coverage a factor in the crystallization of the controversy?}

The media coverage of the geothermal controversy within the EMS did not contribute to situating geothermal energy projects in a comprehensive general context, but instead reinforced the segmentation of the discourses. This is the main result of a content analysis (Krippendorff 2004) we conducted on a corpus of articles published from September 2014 to December 2015 by the regional daily newspaper Les Dernières Nouvelles d'Alsace, (DNA-88 articles) and the Blog de La Robertsau (neighborhood blog). The aim was to establish how the regional newspaper and the blog framed EMS geothermal energy projects, and particularly the Robertsau project, which was the most controversial. Previous studies (Iyengar 1991) have established that news formats about political issues can be "episodic" or "thematic". "The episodic news frame focuses on specific events or particular cases, while the thematic news frame places political issues and events in some general context" (Ibid., p. 2). While the regional newspaper DNA's articles were mainly episodic, the posts published by the Blog de la Robertsau were mainly thematic. As a matter of fact, articles in blogs and in community and municipal outlets published detailed analyses of the projects that always supported their positions (Chavot et al. 2016).

More specifically, the DNA dealt with geothermal energy events or announcements in an apparently "neutral"-meaning "balanced" (Chalaby 1998)-but episodic way. In fact, journalists presented news or actors' discourses and hardly ever advanced personal opinions. They relayed arguments for and against these projects. However, they tended to favor official sources (which mainly support geothermal projects) over residents' groups (which mainly resist them): while official sources were mainly quoted in the most important news sections, residents' groups were given exposure in less important sections such as Letters to the Editor. Also, the DNA quoted promoters of geothermal energy (official sources) in a way that made them the "primary definers" of geothermal energy. ${ }^{8}$ As a result, news reports about EMS geothermal energy projects looked like a disorganized mosaic: discourse fragments from both sides appeared under different headings, but rarely in connection with each other.

The Blog de la Robertsau's administrator and other contributors criticized the way in which official press outlets (such as DNA) favored promoters of geothermal energy and found that the Internet allowed them to bypass the filters imposed by journalistic standards. This is the reason why the case of the Le Blog de La Robertsau is particularly interesting. This blog published 46 articles on the issue during the PI period. Residents' groups were its main source. Thus, this blog favored opponents' quotes and criticized operators. Unlike the short and descriptive articles published by the $D N A$, those published by the Blog de La Robertsau were relatively long and detailed. While the DNA played the role of a "neutral" news provider, the Blog presented itself as a provider of expert information for online readers, and its posts offered a wealth of scientific, technical, legal, political, economic and sociological detail.

${ }^{8}$ Stauffacher et al. (2015) reached the same conclusions. On the concept of primary definers and secondary definers, see Hall (1994). 
Table 3 Participation in public inquiries held in Alsace in 2015/2016

\begin{tabular}{|c|c|c|c|}
\hline $\begin{array}{l}\text { Sites, operators, dates } \\
\text { of public inquiries }\end{array}$ & Total & Negative/positive opinions & $\begin{array}{l}\text { Investigating commissioners' } \\
\text { conclusions }\end{array}$ \\
\hline $\begin{array}{l}\text { Illkirch-Graffenstaden (ES) } \\
\text { April-May } 2015\end{array}$ & 19 & $12 / 7$ & Positive with reservations \\
\hline $\begin{array}{l}\text { Mittelhausbergen (ES) } \\
\text { April-May } 2015\end{array}$ & 138 & $134 / 4$ & Negative \\
\hline $\begin{array}{l}\text { La Robertsau (Fonroche) } \\
\text { April-May } 2015\end{array}$ & $\begin{array}{l}135(\mathrm{Fr}) \\
{[+756 \mathrm{Ger}]}\end{array}$ & $130 / 5$ & Negative \\
\hline $\begin{array}{l}\text { Eckbolsheim (Fonroche) } \\
\text { April-May } 2015\end{array}$ & 86 & $130 / 5$ & Negative \\
\hline $\begin{array}{l}\text { Vendenheim (Fonroche) } \\
\text { Sept-Oct } 2015\end{array}$ & 40 & $34 / 6$ & Positive \\
\hline $\begin{array}{l}\text { Hurtigheim (Fonroche) } \\
\text { Oct-Nov } 2016\end{array}$ & 10 & - & Positive \\
\hline
\end{tabular}

\section{Exploring the spaces of public expression}

Although PIs are organized within the municipality potentially hosting the project, anyone can contribute to the inquiry regardless of whether they are a resident. The degree of involvement in a PI is often perceived as an indication of whether a project is accepted by the population; low participation is seen as equivalent to unconditional acceptance of the project (Blatrix 1996). PIs can also be a platform for expressing discontent and protest. The four PIs organized in the Spring of 2015 in the EMS crystallized the opposition to geothermal projects. Three of them received a significant number of opinions, most of them opposing the projects (Table 3). The records indicate doubts concerning the risks induced by drilling and the reliability of the technical arguments made by the operator. In the Robertsau inquiry, there was a strong mobilization of German citizens: more than seven hundred citizens sent a petition-like form to the investigating commissioner to denounce the risks induced by drilling and oppose the project.

Most opinions were negative. In the Hurtigheim PI, we found questions rather than clearly formalized opinions. Although the subsequent Vendenheim and Hurtigheim PIs had fewer contributions, in both cases, the councils of these municipalities produced negative deliberations. Nonetheless, the IC offered a positive conclusion, meaning that they found enough evidence in the operators' files to remove criticisms and remarks from municipalities and residents.

In what follows we focus on citizen contributions to the four PIs staged in April-May 2015 in the EMS, coded with the Atlas.ti software. Many of the citizens who submitted their opinions to these PIs have knowledge of different aspects of GPs. Nearly a third of them presented structured arguments, referring to different sources of information (Table 4). Another third of contributors presented a set of arguments similar to those presented by community groups or municipalities. The remaining third simply indicated their opposition to the presence of a geothermal plant near their homes.

(Geothermal projects: main examples referred to in citizens' opinions. Prefecture: reference to advisory bodies ${ }^{9}$ or to expert reports connected to the prefecture, $\mathrm{n}=376$ ).

\footnotetext{
${ }^{9}$ Among these bodies, the Permanent Secretariat for Industrial Pollution Problems (SPPPI), hosted by prefecture, plays an important part in establishing dialog between stakeholders. It gathers elected officials, militant groups, industrialists, representatives of the state and institutions. Members get involved in studies or surveys related to industrial environment and/or to local concerns, whose conclusions are discussed during open meetings.
} 
Table 4 Main sources used by citizens during the four Spring 2015 Pls

\begin{tabular}{lc}
\hline Information sources & Amount \\
\hline Operators'files & 84 \\
Geothermal projects (Basel 21, Soultz-sous-Forêts 17, Lochwiller 17, Landau 16, to name only the big- & 79 \\
gest ones) & \\
Positions of municipal councils or elected officials (from Oberhausbergen 18, EMS 16, Strasbourg 11, & 47 \\
Eckbolsheim 2) & 38 \\
Prefecture (SPPPI 21, Autorité environnementale 7, DREAL 6, others 4) & 18 \\
Politicians & 18 \\
Media & 17 \\
Scientific experts (Scientists 13, BRGM 2, ADEME 2) &
\end{tabular}

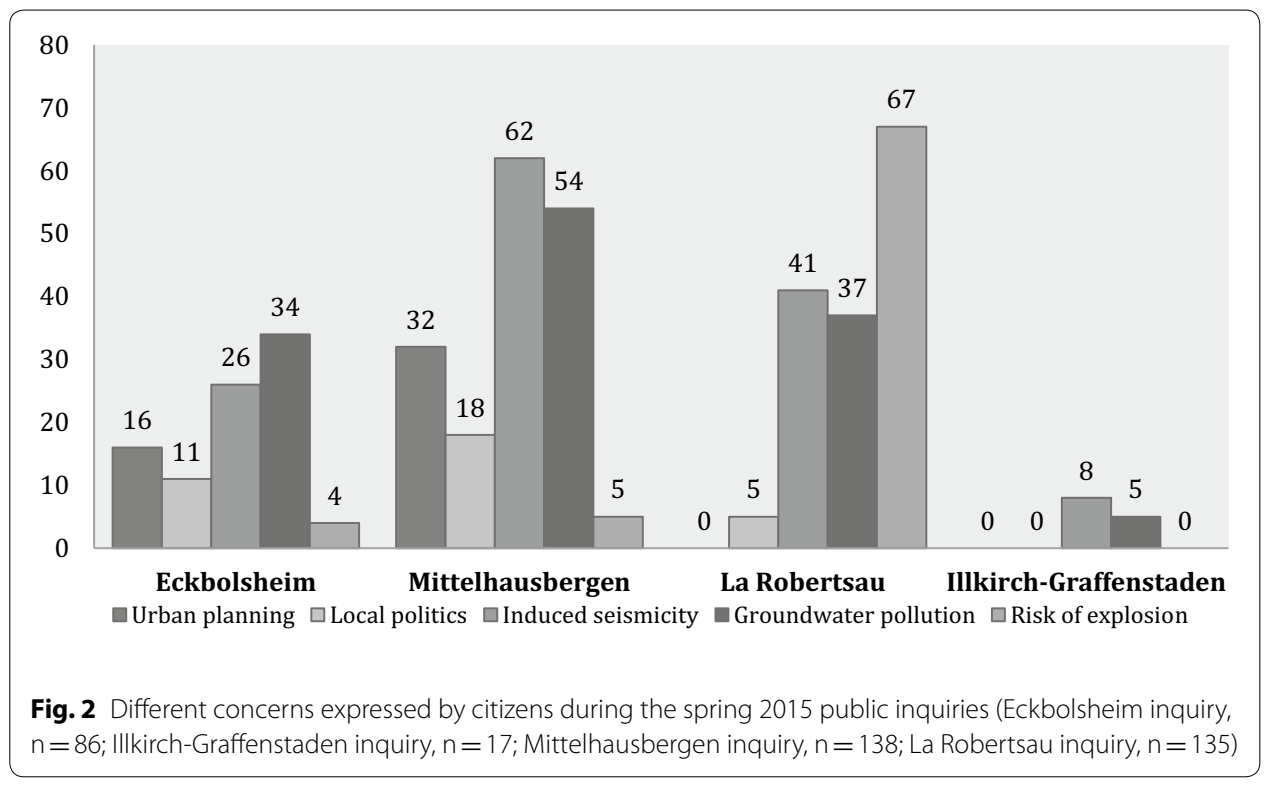

Inhabitants criticized the projects because of their risks and potential consequences for the environment and infrastructure, but also noted the lack of a clear, consistent energy policy at the local level. However, local residents did not attribute equal importance to these elements from one PI site to another (Fig. 2). Thus, during the PI conducted at La Robertsau, the majority of criticisms pertained to the risks induced by the project, particularly the explosion risk due to the presence of a highly flammable gas used for electricity production. In Eckbolsheim and Mittelhausbergen, the PI revealed concerns about the absence of a concerted policy between the Eurometropolis of Strasbourg and its municipalities. Thus, projects were understood differently from one context to another, even if they were only a few kilometes apart, which reveals the necessity of researching social and cultural factors in each context. 


\section{Understanding the dynamics of acceptance and opposition to GPs Locally anchored projects versus unbound projects}

We argue that the population's sympathy for a geothermal project largely depends on how the project is initiated, discussed and presented to the local community, i.e., on whether it is a locally anchored or an unbound project. This distinction (locally anchored versus unbound projects) takes into account the manner in which the operators consider their interactions with the communities. In the case of locally anchored projects, the company appears to adopt an attentive approach towards local communities, letting them define the outlines of the projects before taking steps to implement them. In Illkirch-Graffenstaden, dialog between elected officials and the operator Electricité de Strasbourg (ES) began as soon as 2009 , after the city requested an initial assessment of the geothermal potential of the subsoil from the French geological survey organization (the Bureau de recherches géologiques et minières, BRGM).

In this case, the City of Illkirch-Graffenstaden commissioned the project and chose the operator. Thus, interactions with the operator took place before the procedure to obtain an exclusive license to prospect was launched (Cf. Table 2). The partnership was facilitated because ES had a long-standing relationship with local authorities for electricity distribution, and appeared to be willing to do the same for heat distribution. ${ }^{10}$ Residents have since been regularly informed about the project's progress through the municipal newspaper, which has popularized technical aspects of the project (Bodin et al. 2018). The same process has occurred in the Wissembourg area, where actions were initiated by several groups of municipalities (communautés de communes). The project is regularly presented in the local press and municipal magazines, and a group of elected people and a regional agency had been mandated to prospect and find industrial partners to purchase geothermal heat. ${ }^{11}$ Overall, these projects were initially perceived as useful for the future of the territory and co-defined by the local authorities and the operator.

This dynamic contrasts with the dynamic around unbound projects, such as those of Eckbolsheim, La Robertsau and later Vendenheim. New operators who entered the geothermal energy sector in early 2010 initiated projects without establishing a local dialog. The preliminary steps, i.e., the application for an exclusive research license, were taken without informing the inhabitants concerned, as local public inquiries are not required by law in the context of high-temperature projects. ${ }^{12}$ In these cases, local authorities were not initiators or partners in the projects. Only the central technical services of the EMS were occasionally consulted on logistical aspects, such as the choice of project location. ${ }^{13}$ The public was informed and consulted through the PIs procedure only after the main characteristics of the project had been settled (location, deepness of the

\footnotetext{
10 This partnership-like relation is mentioned in the interviews conducted with operators and local elected officials. In the document submitted to the PI, the operator wrote that geothermal project products would be used to supply heat to district heating networks.

11 See for instance the June 2013 issue of the municipal bulletin L'actualité de Wissembourg, d'Altenstadt et de Weiler, p. $13-17$.

${ }^{12}$ In the case of request for a high-temperature exclusive licence to prospect no publicity is made about the request and the possibility for citizens to give their opinion on the request.

13 Interviews with EMS officers in charge of environment and energy transition and several elected officials, as well as files furnished by industrialists during the PIs, helped figure out the nature of the negotiation between operators and local institutions in the early stages of the project.
} 
drilling, risk analysis) and the project appraised by the environmental agency. These projects developed without upstream consultation or dialog involving local communities faced resistance during the PIs or in the initial phases of project implementation. This was the case for the Robertsau and Eckbolsheim projects. However, we will see that the social dynamics of opposition to projects varied from one context to another because the actors involved in the controversy were linked to different social worlds: that of residents' groups in the case of La Robertsau and those of local politics and governance in the case of the western municipalities of the EMS. Some oppositional movements gained force and cohesion from their shared social identity, as in the case of La Robertsau (see below).

\section{When local politicians and governments appropriate GPs}

The mining code that applies in the case of geothermal projects gives the state and mandated companies the responsibility to organize the exploitation of subsoil wealth. However, local political actors play key roles in the way GPs are understood by local residents. These actors' attitude towards GPs primarily depends on their upstream commitment to the project, which depends on the political line defended locally, particularly in terms of environmental and urban planning.

Below, we focus on two specific cases to compare the quality of the interactions between GP promoters, politicians and the general population-i.e., to ascertain whether the project was discussed locally with elected people and citizens-as well as to consider the role of the environmental, sociological, political and economic contexts. The interactions that occurred mirror the locally anchored/unbound nature of the projects. As we will see, the social and political momentums reflected by the project discussions can be very different.

\section{First case: Local governments list GE in its agenda (locally anchored projects)}

As noted above, the residents of Illkirch-Graffenstaden did not oppose the project. In this city, a dominant green and socialist coalition has backed environment and energy policy since the late 1990s. The city defined its own climate plan in the mid-2000s and initiated geological surveys to exploit subsoil resources. It was looking for alternative heat sources to power its urban heat network, and geothermal energy occupied a strategic place in local policy. Thus, GE entered the local political agenda and became an intersection between the political social worlds (as in the Green movement) and the world of local councils of EMS, which shared the same interest in renewable energies as in Illkirch-Graffenstaden.

In Northern Alsace, geothermal energy is also promoted by elected officials from the Socialist and Green Parties, i.e., in Soultz-sous-Forêts or Wissembourg. There, the exploitation of underground resources is part of the social identity of the local community, who have experienced oil drilling for decades. As the mayor of Soultz-sous-Forêts notes, "Underground energy is in our DNA". ${ }^{4}$ Thus, GE entered the political agenda for at least two reasons. First, it fits the political sensibility of the elected officials (they are

${ }^{14}$ This argument was repeated on numerous occasions by the Mayor of Soultz-sous-Forêts in several public meetings related to geothermal energy. 
mandated to pursue environmentally friendly policies). Second, it helped them to reconnect with the industrial past of the territory, as the installation of geothermal power plants (potentially greener and cheaper energy) is supposed to attract new industries on a traditionally industrial land. In this context, lack of public acceptance does not appear to be an issue. The mayor of Soultz-sous-Forêts was often invited to public meetings to advocate geothermal energy. This ultimately appears to be a case in which the projects were rooted in the history of the territory and met the communities' expectations.

\section{Second case: The imposition of geothermal projects in urban areas (unbound projects)}

As a result of government measures to promote energy transition, in early 2010, the operators Fonroche and ES designed several projects to be implemented in the EMS. While these projects appeared to fit with the energy climate plan developed by the EMS (although it had no concrete plan to accompany the projects), they are unbound projects if we consider the small amount of upstream interactions between the operators and the municipalities or neighborhoods potentially hosting the projects.

Thus, these GPs entered the political agenda via a different path than locally anchored projects. In the small towns of the western sector of the EMS, including Eckbolsheim and Oberhausbergen, elected officials felt it was important to oppose these projects to reaffirm the sovereignty of their communities for the future of their municipalities. For a few decades, these municipalities have been deeply transformed by the development and increased attractiveness of the EMS (their population has doubled during the last 20 years). However, the elected officials of these municipalities are not on the same side as the political majority of the EMS council and as a result have little influence on the decisions taken there. Thus, opposing GPs may also be a way to make their voice heard in that council and provide coherence to their inscription in the social world of elected officials of peri-urban municipalities. ${ }^{15}$

In the deliberations of the municipal councils of these towns, several arguments were voiced in support of the rejection of GP, in addition to the focus on induced risks: the absence of an energy master plan in the EMS, the negative impact of these projects on the municipal development plans, and errors of judgment by the operators (who, according to the Oberhausbergen municipal council, did not choose the right location, supposedly too far from the fault it intended to exploit and from the heating networks it was expected to power).

However, each municipality had its own way of opposing the projects. In Oberhausbergen, whose municipal territory is bordered by the Eckbolsheim and Mittelhausbergen projects, the municipal council firmly rejected the projects as long as the Eurometropolis would not develop "a medium- and long-term master plan for the production and distribution of energy [...], consistent with the urban planning and development and environmental protection orientations of the Metropolitan PLU [Local Urban Plan]". ${ }^{16}$

\footnotetext{
15 Our observations of public meetings on GPs organized in peri-urban municipalities and interviews organized with elected officials show a shared interest in opposing GPs, at least in 2015-2017. In fact, these elected officials share more than this opposition to GPs; they share membership in the same political social world, which may experience extensive reconfigurations according to the policy implemented in the EMS context.

16 Deliberation of the Oberhausbergen Municipal Council of 20 May 2015, p. 5.
} 

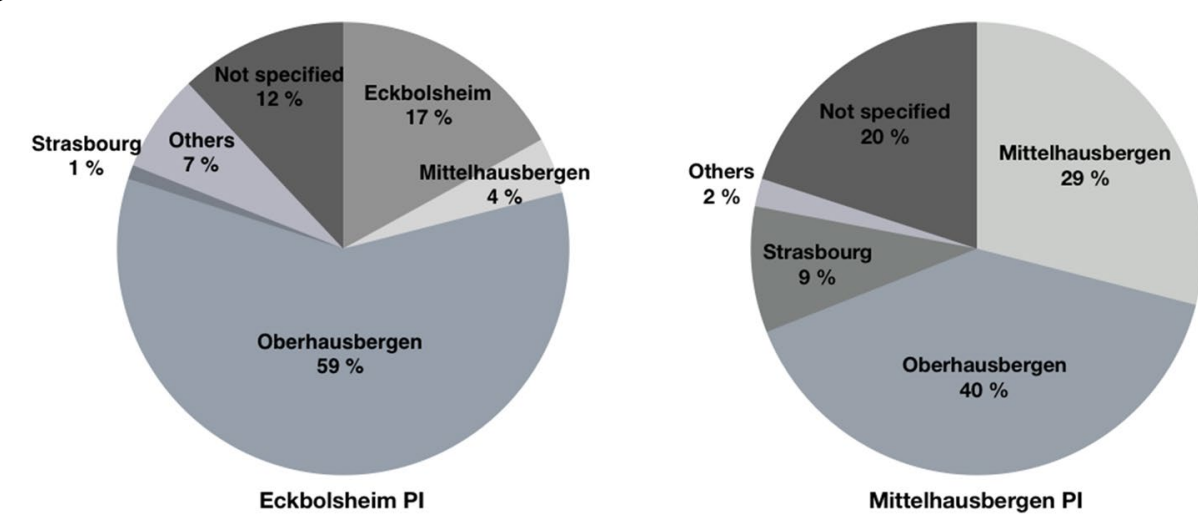

Fig. 3 Participation in the Eckbolsheim and Mittelhausbergen public inquiries by area of residence

The town used multiple means to get local residents to participate in the Eckbolsheim and Mittelhausbergen PIs (Fig. 3): the GP was placed on the agenda of the district council meetings, and the town hall organized public meetings and drafted notes and articles that appeared in the municipal paper.

The elected representatives of Eckbolsheim were more amenable to GPs. Interested in the principle of geothermal energy, they noted in a May 2015 deliberation "the difficult acceptability by the population of a project likely to generate risks without benefits in return" ${ }^{17}$ Therefore, the municipality engaged in negotiations with the company and the EMS to make sure that it stood to benefit from the presence of the drilling site. However, the municipal council did not call for the mobilization of local residents and only a dozen Eckbolsheim residents were involved in the PI (compared to 90 inhabitants from the neighboring village of Oberhausbergen). In these two towns, elected representatives demonstrated their willingness to take charge of the debate and defend the interests of their town: this was a question of restoring sovereignty to determine their future (Bodin et al. 2018). In this context, the publicity around the risks related to geothermal projects legitimated the approach of elected officials and helped them to gain support from residents.

\section{The case of La Robertsau: "do not add risk to risk"}

During the PIs, several concerns were put forward by local residents (Fig. 4). Induced seismicity and groundwater pollution were the most frequently cited. Two other risks were noted more locally. In the western sector of the EMS (Eckbolsheim and Mittelhausbergen PIs), local residents brought up the risk of interaction between two drilling projects located barely two kilometers apart and noted that the operators involved had not looked into the issue. In the Strasbourg district of La Robertsau, many residents expressed concern about the risk of explosion induced by the use of a highly flammable gas in the heat exchanger used for electricity production. ${ }^{18}$

\footnotetext{
${ }^{17}$ Deliberation of the Eckbolsheim Municipal Council of May 11, 2015, p. 6.

18 By comparison, only noise and induced seismicity were frequently mentioned as nuisances during an acceptability survey conducted near the Soultz-sous-Forêts power station in 2012 (Lagache et al. 2013).
} 


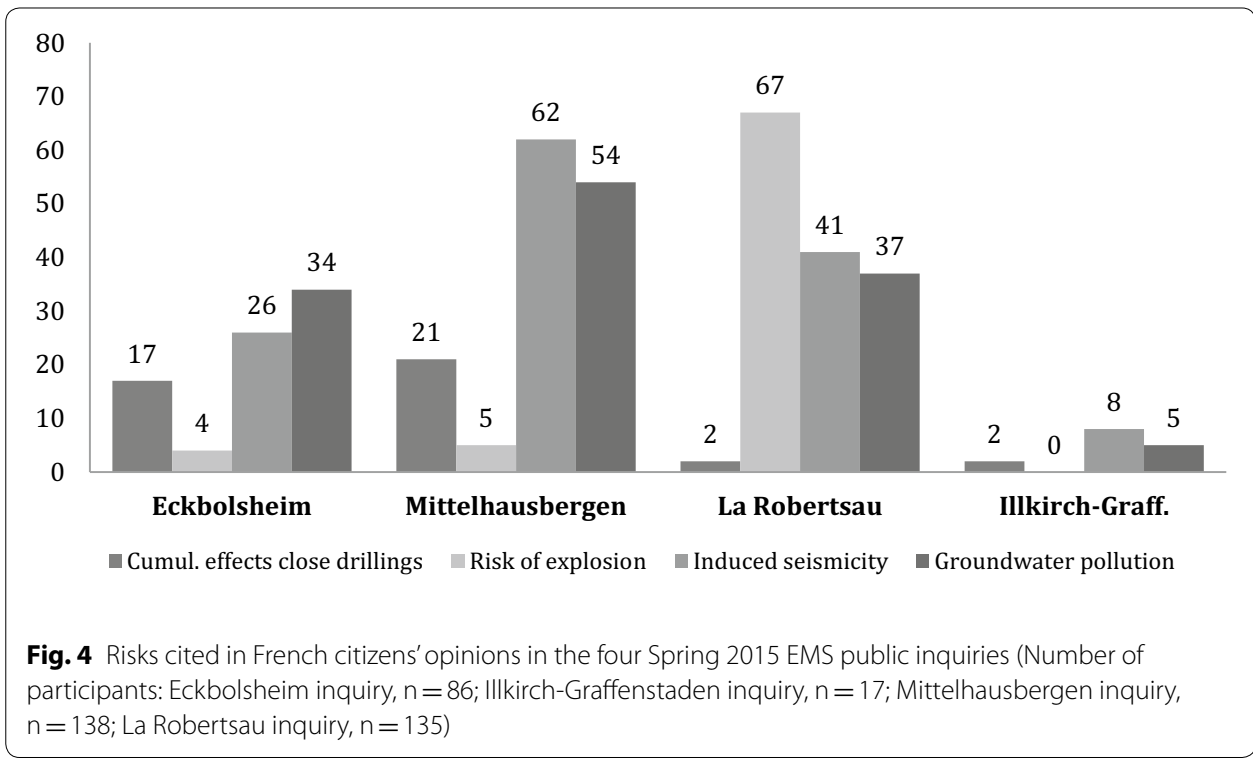

Among the three controversial projects in the EMS, the Robertsau project was particularly contested. There, the social perception of risks had a higher influence on the proceedings than in other cases. The drilling project was to be implemented on a site near the "oil port" (Port au pétrole) where several hundred thousand cubic meters of petroleum and chemical products are stored. The protest against the project was orchestrated by the Robertsau residents' association (l'Association de défense des intérêts de la Robertsau-ADIR), which works to preserve the neighborhood's environment. The association noted the risk of explosion and the seismic risk and discredited the company in charge of implementing the project by alerting residents to its lack of prior experience.

The Robertsau controversy grew for two reasons. First, in addition to the fear of new drilling hazards, this project posed a double threat to the social identity of residents, represented by the ADIR. In the past, this group and La Robertsau's inhabitants had been involved in many governance conflicts, such as negotiations on the route of the tram line running across the neighborhood, the urban development plan, and the reduction of risks within the industrial zone near the oil port. This daily resistance effort against the urbanization policy of the city of Strasbourg and the EMS brought together local residents. More recently, the ADIR had been involved in the Technological Risk Protection Plan (PPRT) of the oil port since early 2010. In that context, it was campaigning for a transformation or relocation of the industrial park. At the very least, it sought to ensure that no new risk-generating enterprises would be established in this area. The drilling project, indeed, embodied precisely what the ADIR was fighting against. Furthermore, the group has long practised local democracy on a neighborhood scale. The absence of local debate on the project went against these democratic principles. Thus, the project and the way in which it was imposed ignored the connection between ADIR members and their territory, their social identity, and their aspirations and projects for its future. The GP appeared to be both "unbound", far removed from any reality on the ground, and a threat to the social identity of ADIR members. 
Second, focusing on the idea that one should not add risks to an already sensitive area allowed ADIR members to count on important allies. La Robertsau is an affluent residential district where some of Strasbourg's (political and academic) elite resides. By March 2015, all the candidates for the departmental elections for the north-eastern sector of Strasbourg had stated their opposition to the project. Shortly before the public inquiries began, the City of Strasbourg announced that it would give a negative opinion on the Robertsau project (DNA/17 April 2015). Ultimately, through the actions of the collective of community groups and politicians' statements, the Robertsau project was the most discussed in the local media and served as a reference point in debates related to other projects. ${ }^{19}$

The conclusions of the PI on the Robertsau project emphasized that the industrial operator was not successful in reassuring the residents and did not provide convincing arguments, unlike its critics. The commissioner in charge of the inquiry argued that the project should be postponed or abandoned based on the application of the precautionary principle. The company dropped the project soon after the PI. At the end of the 2015 PI process, two projects were withdrawn (La Robertsau and Mittelhausbergen), and two others were validated by prefectural decree. ${ }^{20}$

\section{Discussion and conclusion}

The purpose of this article was first of all to examine how local governance may conflict with the state framework in the field of energy transition. We have scrutinized the development of deep geothermal projects (GPs) in Alsace and proposed the distinction between locally anchored and unbound project to clarify how relationships between local governance and promoters may affect the social acceptance of a project. In the case of the two locally anchored projects, i.e., Illkirch-Graffenstaden and Wissembourg, upstream discussion and partnerships between operator and municipal government have reinforced the coherence of the project with local policy, which may have facilitated its acceptance by the local population. Conversely, imposing geothermal projects without prior debate, merely invoking energy transition-as has been the case for the unbound projects of La Robertsau and Eckbolsheim - has generated lasting, and sometimes violent misunderstandings between operators, local elected officials and residents. It appears overall that disseminating information upstream and encouraging public input is necessary to facilitate the social acceptance of a project. In any case, a project will be better understood if residents can discuss it, make contributions, and have the opportunity to reject it.

The second perspective developed in this article has consisted in scrutinizing the different forms that mobilization for or against GPs can take. If the potential for development of a GP depends on the geophysical characteristics of a territory, its concretization cannot disregard the social and cultural dimensions of that territory. In this context,

\footnotetext{
${ }^{19}$ Of the 81 works on PM projects published in the DNA from 2014 to Dec 2015, 29 articles are dedicated to the Robertsau project, and the debates there are referenced in 18 other articles.

20 A third project located on an industrial wasteland between Vendenheim and Reichstett in the north of the EMS was approved by the prefecture in April 2016. This project was presented as having a pivotal role in the transformation of a former oil refinery into an industrial ecopark. However, this was an unbound project, conducted without prior consultation with local residents.
} 
using the concepts of social worlds and of social identity is fruitful. They help us to understand how political and strategic choices related to geothermal energy are made by referring to the stakeholders' integration into a more or less structured group or community. As we have seen, in EMS and Northern Alsace, the positioning of both proponents and opponents to geothermal projects can be related to their policies (either in line or opposed to the green-socialist coalition dominant within the EMS or to the green movement in Northern Alsace) and to the role they intend to play in municipal life. In that context, the adoption or rejection of a project is not as important as what this posture may represent for the community to which one belongs or represents.

Taking into account the social identity of a community sheds light on the meanings that politicians, local association and residents give to geothermal projects. In IllkirchGraffenstaden and Northern Alsace, geothermal energy fits with long-lasting environmental policies and actions-engagement in local climate plans, for instance-and sustainable economic development, consistent with local social identities. On the opposite, in the western municipalities of EMS and in the Robertsau sector, the geothermal project disrupts the local communities' sets of values, practices and engagements, starting with the attachment to local democracy and to the right to have a say in environment and urban development projects. This diversity of social meanings given to GP is associated with very different visions of the risks involved. As we have seen, discussions about risks occupy a central place in the controversies surrounding GPs, both in La Robertsau and in the western sector of the EMS. However, the emphasis on the risks involved in the GP debate may serve different logics. In La Robertsau, it enabled the banishment of the GP from the industrial zone of the oil port in order "not to add risk to risk". In that case, dealing with risk and the desire to reduce the number of risky installations in the neighborhood is inscribed in the social identity of La Robertsau residents, in effect legitimizing the opposition to the GP. In the western communities of the EMS, publicity about the risks involved plays a more rhetorical role. It provides the necessary foundation for a set of demands by the small municipalities directed toward the operator and EMS. Because the installation of a geothermal power plant is "costly" in terms of risks, the municipality can ask for compensation, which can be financial (sharing royalties) or political.

Overall, the reasons to oppose a project are not to be seen as irrational fear regarding the risks induced by drilling or as a type of NIMBY selfishness fuelled by ignorance of the technical or/and ecological specifics of the projects. Rather, they are related to each stakeholder's social situation, their inscription in different social worlds and their social identity. For the inhabitants, opposing a geothermal project is a matter of protecting their territory, preserving a lifestyle and an environment, and, for local elected officials, it is about reaffirming the sovereignty of their communities and deciding the future of their region. In addition, the diversity of social worlds and social identities and the way they affect the perception of risks suggests that the governance of GPs should be reconsidered. Whenever possible, an effort should be made to provide information upstream and facilitate citizens' engagement, as is the case for locally anchored projects. Projects that appear to be disconnected from local concerns or to only involve minor participation of elected officials and local citizens risk being perceived as imposed from the top down and thus potentially rejected. This happened with the two PIs related to 
the unbound projects of Eckbolsheim and La Robertsau, in which the projects were presented to the public in a near-final form. As a consequence, residents denied legitimacy to the project. And this denial, fed by representations and values anchored in the territory, can lead to durable misunderstandings among residents, the project promoters and local institutions.

\begin{abstract}
Abbreviations
ADEME (Agence de l'environnement et de la maitrise de l'énergie): French Environment and Energy Management Agency; ADIR: Association de défense des intérêts de la Robertsau; BRGM (Bureau de recherches géologiques et minières): French geological survey organization; DREAL (Direction régionale de l'environnement, de l'aménagement et du logement): Regional Directorate for Environment, Development and Housing; EDF: Electricité de France; EGS: enhanced geothermal system; EMS: Eurometropolis of Strasbourg; GE: geothermal energy; GP: geothermal project; IC: Investigating commissionner; PI: public inquiry; PPRT (Plan de prévention des risques technologiques): Technological Risk Protection Plan; RE: renewable energy.
\end{abstract}

\title{
Authors' contributions
}

All authors contributed to data collection and analysis. PC and CH wrote the draft version for the 2017 Karlsruhe 5th EGW workshop. PC and AM prepared the draft of this version, which was revised by the co-authors. All authors read and approved the final manuscript.

\section{Author details}

${ }^{1}$ LISEC, University of Strasbourg, 7 Rue de I'Université, 67100 Strasbourg, France. ${ }^{2}$ CREM, University of Lorraine/University of Strasbourg, Île du Saulcy, BP 60228, 57045 Metz Cedex 01, France. ${ }^{3}$ SAGE, University of Strasbourg, 5 allée du Général Rouvillois, CS 50008, 67083 Strasbourg Cedex, France.

\section{Acknowledgements}

This work was conducted within the framework of the European Union's Horizon 2020 DESTRESS project (Grant Agreement 691728) and of the EGS Alsace project, co-funded by ADEME and ES. We thank the LabEx G-EAU-THERMIE PROFONDE (University of Strasbourg, CNRS, ES), which is co-funded by the French government under the "Investissements d'Avenir" program, for their financial support. This article also received support from the Maison Interuniversitaire des Sciences de l'Homme d'Alsace (MISHA) and the Excellence Initiative of the University of Strasbourg. We thank Nicolas Daigneault and Jean-Yves Bart for their work on the English version of the text. The authors are grateful to the editor and to the reviewers for their helpful comments and advice.

\section{Competing interests}

The authors declare that they have no competing interests.

\section{Availability of data and materials}

All information and data necessary to understand the results and conclusions drawn in the paper are in the text, tables, and figures or can be found in cited references.

\section{Funding}

Not applicable.

\section{Publisher's Note}

Springer Nature remains neutral with regard to jurisdictional claims in published maps and institutional affiliations.

Received: 17 April 2018 Accepted: 9 November 2018

Published online: 23 November 2018

\section{References}

Batellier P. Acceptabilité sociale. Cartographie d'une notion et de ses usages. Cahier Recherche. Québec: UQÀM; 2015. Bodin C, Chavot P, Masseran A, Serrano Y, Heimlich C, et al. Les formes d'appropriation de la transition énergétique par le récit territorial municipal: le cas de la géothermie profonde dans la métropole de Strasbourg. Les Enjeux de I'Information et de la Communication. 2018;19/3A;69-80. https://lesenjeux.univ-grenoble-alpes.fr/2018-supplement $\mathrm{A} / 05 / 2018$.

Blatrix B. Vers une démocratie participative? Le cas de l'enquête publique. In: Chevallier J, editor. La gouvernabilité. Paris: PUF; 1996. p. 299-313.

Boissavy C, Rocher P, Laplaige P, Brange C (2016) Geothermal Energy Use, Country Update for France. Paper presented at the European Geothermal Congress 2016, Strasbourg, 19-23 September 2016.

Carr-Cornish S, Romanach L. Differences in public perceptions of geothermal energy technology in Australia. Energies. 2014;7(3):1555-75.

Chalaby JK. The invention of journalism. Basingstoke: Macmillan; 1998.

Chavot P, Masseran A, Bodin C, Serrano Y, Zoungrana J. Geothermal energy in France. A resource fairly accepted for heating but controversial for high-energy power plants. In: Pellizzone A, Manzella A, Allansdottir A, editors. Geothermal energy and society. Springer: Lecture Notes in Energy; 2019. p. 105-22. 
Chavot P, Masseran A, Serrano Y (2016) Information and public consultation exercises concerning geothermal projects. "The Strasbourg case". Paper presented at the European Geothermal Congress 2016, Strasbourg, 19-23 September 2016

Devine-Wright P. Place attachment and public acceptance of renewable energy: a tidal energy case study. J Environ Psychol. 2011;31(4):336-43.

Garrety K. Social worlds, actor-networks and controversy: the case of cholesterol, dietary fat and heart disease. Soc Stud Sci. 1997;25:727-73.

Gendron C. Penser l'acceptabilité sociale: au-delà de l'intérêt, les valeurs. Rev Int Com Soc Pub. 2014;11:117-29.

Gieryn T. Cultural boundaries of science: credibility on the line. Chicago: University of Chicago Press; 1999.

Hall S. Codage/décodage. Réseaux. 1994;12:27-39.

lyengar S. Is anyone responsible?: How television frames political issues. Chicago: Univ. of Chicago Press; 1991.

Krippendorff K. Content analysis: an introduction to its methodology. SAGE: Thousand Oaks; 2004.

Lagache L, Genter A, Baumgaertner J, Cuenot N, Koelbel T, Texier P, Villadangos G. How is evaluated acceptability of an EGS project in Europe: the Soultz-Kutzenhausen geothermal project. Paper presented at the European Geothermal Congress 2013, Pisa, Italy, 3-7 June 2013.

Meller C, Schill E, Bremer J, Kolditz O, Bleicher A, Benighaus C, et al. Acceptability of geothermal installations: a geoethical concept for GeoLaB. Geothermics. 2018;73:133-45.

Pellizzone A, Allansdottir A, De Franco R, Muttoni G, Manzella A. Geothermal energy and the public: a case study on deliberative citizens' engagement in central Italy. Energy Policy. 2017;101:561-70.

Stauffacher M, Muggli N, Scolobig A, Moser C. Framing deep geothermal energy in mass media: the case of Switzerland. Technol Forecast Soc Change. 2015;98:60-70

Wynne B. Misunderstood misunderstanding: social identities and public uptake of science. Public Underst Sci. 1992;1:281-304

\section{Submit your manuscript to a SpringerOpen ${ }^{\circ}$ journal and benefit from:}

- Convenient online submission

- Rigorous peer review

- Open access: articles freely available online

- High visibility within the field

Retaining the copyright to your article

Submit your next manuscript at $\boldsymbol{s p r i n g e r o p e n . c o m ~}$ 